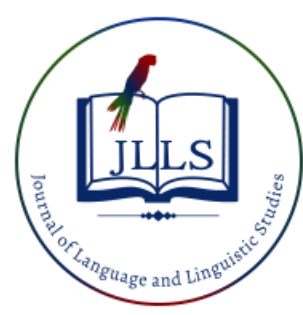

Available online at www.jlls.org

JOURNAL OF LANGUAGE AND LINGUISTIC STUDIES

ISSN: $1305-578 \mathrm{X}$

Journal of Language and Linguistic Studies, 16(4), 1747-1759; 2020

\title{
Turkish textbooks in terms of thematic vocabulary coefficient
}

\author{
Yavuz Selim Bayburtlua ${ }^{\text {a1 }}$ \\ ${ }^{a}$ Ministry of National Education, Antalya, Turkey
}

\section{APA Citation:}

Bayburtlu, Y. S. (2020). Turkish textbooks in terms of thematic vocabulary coefficient. Journal of Language and Linguistic Studies, 16(4),1747-1759.

Submission Date:03/06/2020

Acceptance Date:23/08/2020

\begin{abstract}
This study was conducted to determine the vocabulary coefficients of the themes in 7 Turkish textbooks taught during the 2019-2020 academic year. The study of the vocabulary coefficients of the themes is a method specific to the claim of the research. There are subject scopes and concept areas specific to the themes in the Turkish textbooks. The texts of themes were selected according to the concept subject scope and concept areas. As the vocabulary coefficients of the selected texts vary accordingly, the vocabulary coefficients of the Turkish textbooks were calculated thematically. The results showed that the vocabulary coefficients of the Turkish textbooks were low. It was observed that none of the themes of the 7 textbooks examined had vocabulary coefficients at the level of good or very good. It was understood that the Turkish textbooks were not sufficient in teaching vocabulary to students and that the Turkish curriculum was insufficient to realize the predicted learning outcomes. The vocabulary coefficients of the themes in the examined textbooks were as follows: 0.3370475 in the 5th grade Turkish textbook by Anittepe publishing, 0.3021508 in the 6th grade Turkish textbook of Ministry of National Education (MONE) publications, 0.33444094 in the 6th grade Turkish textbook of Ekoyay publishing, 0.3327491625 in the 7th grade Turkish textbook of Özgün publications, 0.348125375 in the $7^{\text {th }}$ grade Turkish textbook by MEB, and 0.321079125 in another Turkish textbook by MEB (Editor Emine KIRMAN). It was concluded that coefficient of the themes of the 8th grade Turkish textbook examined was 0.334793675 .
\end{abstract} (C) 2020 JLLS and the Authors - Published by JLLS.

Keywords: thematic vocabulary; thematic vocabulary coefficient; vocabulary coefficient

\section{Introduction}

Turkish teaching is conducted in accordance with the Turkish lesson plan. The Turkish course curriculum was updated in 2019. The curriculum was created with an approach of preparing in themes as in previous years. The theme concept refers to ideas, opinions, views, and the main subject addressed in a text (TDK, 2005). Eight themes are taught throughout the year in the middle school Turkish textbooks. Themes are selected and incorporated in the books by the authors of the Turkish textbooks. Themes are explained in the Turkish curriculum. Themes that are mandatory to teach in every grade level include "virtues", "our national culture", "national struggle and Ataturk" (MEB,

\footnotetext{
1 Corresponding author.

E-mail address: yavuz.selim.07@ hotmail.com
} 
2019, p.13). In addition to these three themes, the textbook author would determine the five remaining themes. Each of the themes focuses on the main topic, and in the context of these main topics, there are texts. The purpose is to provide students with the learning outcomes determined for each grade level through texts, text-related activities, questions before and after text, and theme evaluation questions. The texts in the Turkish textbooks contribute to enriching learning outcomes such as general culture, various rules and norms, and vocabulary in addition to the learning outcomes listed in the Turkish curriculum. The Turkish curriculum is envisioned to enrich students' vocabulary. The main material of Turkish education is Turkish textbooks. Therefore, the vocabulary development of students is achieved mainly through Turkish textbooks. It is very important that the texts in Turkish textbooks are designed to improve students' vocabulary. Texts in Turkish textbooks are presented according to themes. Texts are selected according to the content of the theme determined by the author of the textbook. There are no criteria for the volume of vocabulary that the selected texts should have. What kind of vocabulary should students learn at the $5^{\text {th }}, 6^{\text {th }}, 7^{\text {th }}$, and $8^{\text {th }}$ grades? Are there any criteria for texts included in Turkish textbooks? The answer to these questions is unknown. The main problem in this issue is that the words to be taught at each grade level are not revealed (Kurudayioğlu \& Soysal, 2016).

\subsection{Literature review}

When the texts in textbooks were examined, it was determined by various researchers that each book has a different vocabulary volume. It is seen that the words used in some texts appear to be rich in the volume of vocabulary, but consist of repetitions, and that attention is not paid to the selection of texts consisting of different words (Öz, 2012). Research shows that texts in Turkish textbooks do not aim to improve students' vocabulary and that vocabulary teaching is carried out without plan (Aru Akyüz \& Espino 2014). This situation is thought-provoking in terms of teaching Turkish. Some researchers express that there has been a vocabulary teaching problem stemming from Turkish textbook authors since the past (Karagöl\&Tarakc1,2019). Similar studies in the field showed that Turkish textbooks are weak in the vocabulary acquisition outcome and that weakness has never changed from the past to the present (Karadağ, 2019). It was understood that vocabulary is not considered in texts in textbooks and ignored by the authors when preparing Turkish textbooks (Karadağ\&Kurudayığlu,2010). The Turkish curriculum envisions the teaching of 8 themes at each grade level. The research in the field revealed that the lack of texts in Turkish textbooks for vocabulary as a learning outcome has not been resolved for a long time. Determining a constant volume of vocabulary for each text in textbooks would be a limiting approach. Instead, it is thought that if the vocabulary coefficients that the 8 themes should have at each grade level are standardized and gradually determined, the shortcomings in vocabulary acquisition in the field may constitute a roadmap. For this purpose, the thematic vocabulary coefficients of texts in Turkish textbooks were calculated. The vocabulary coefficient was proposed by Karadağ (2018) as a variable in language education studies. A vocabulary coefficient is obtained by dividing the total number of unique words in a text by the total number of words in the texts. This value is shown by Karadag between 0 and 1 . As the vocabulary coefficient value approaches 1 , the vocabulary of the text is considered to be rich (Karadağ,2018). As a thematic approach is taken in teaching Turkish, each theme's vocabulary coefficient has been revealed.

\subsection{Research questions}

In alignment with the purpose of the research, the following questions were asked.

1. What are the vocabulary coefficients of the texts related to the eight themes in the 5thgrade Turkish textbook? 
2. What are the vocabulary coefficients of the texts related to the eight themes in the $6^{\text {th }}$-grade Turkish textbook?

3. What are the vocabulary coefficients of the texts related to the eight themes in the $7^{\text {th }}$-grade Turkish textbook?

4. What are the vocabulary coefficients of the texts related to the eight themes in the $8^{\text {th }}$-grade Turkish textbook?

\section{Method}

This is a case study to reveal the vocabulary coefficients of texts in Turkish textbooks. In case studies, the researcher has the opportunity to thoroughly examine one or more cases with various documents (Creswell, 2017). The Turkish textbooks used in the 2019-2020 academic year were examined by document analysis method. In the study, as the materials to be examined are written documents, the data were selected carefully to fit the purpose of the study (Baş, 2011). The vocabulary coefficients of themes in Turkish textbooks prepared with a thematic approach were determined. In examining the vocabulary coefficients in themes, the contributions of themes' concept areas that could influence vocabulary have been effective. The contribution of the concept areas of the themes to the vocabulary has been effective in analyzing the vocabulary coefficients as themes.

\subsection{Data collection and analysis}

Turkish textbooks used in the 2019-2020 academic year were examined in the study. After completing a document analysis on the reviewed textbooks, the data obtained were evaluated with descriptive analysis. Quantitative data obtained were divided into categories in tables. Descriptive analyses of quantitative data were performed and presented under the tables. Due to the exploratory case study's nature, explanations were provided on the data obtained (Yin, 2017). The Turkish textbooks reviewed are: Middle School and Imam Hatip Middle School 5th grade Turkish textbook by Anittepe Publications (2019), Middle School and Imam Hatip Middle School 6th grade Turkish textbook by MEB Publications (2019), Middle School and Imam Hatip Middle School 7th grade Turkish textbook by MEB Publications (2019), Middle School and Imam Hatip Middle School 7th grade Turkish textbook by Özgün Publishing (2019), Middle School and Imam Hatip Middle School 7th grade Turkish textbook by MEB Publications (2019), Middle School and Imam Hatip Middle School 8th grade Turkish textbook by MEB Publications (2019). A total of 7 textbooks with 1 being the 5th grade, 2 being 6 th grade, three 7 th grade, and one 8th grade textbook. Texts and free-reading texts in the textbooks examined were included in the study. The coefficients of 8 themes in the textbooks were calculated.

Vocabulary coefficients of the texts in the examined textbooks were classified according to the vocabulary coefficient assessment scale developed by Bayburtlu (2019). Random readings of 2 field experts provided a contribution to the validity and reliability of the study. The field experts reviewed 1 theme randomly selected from each of the textbooks examined. The data identified as a result of the reviews of the field experts were consistent. The data from the field experts and the researcher were calculated by the consensus/consensus+disagreement formula (Miles \&Huberman, 1994). With this formula, the reliability goodness of fit of the study was found to be 0.92 . This rate shows that the data obtained in the study are reliable. 
Table 1. Vocabulary Coefficient Evaluation Scale

\begin{tabular}{l} 
Points \\
\hline 4 (Very good) \\
If a value between $0.61-1$ is obtained through dividing the number of different words \\
used in the text by the total number of words, the word repetitions in the text are \\
considered to be insignificant, the text is rich in vocabulary and very good in terms of the \\
vocabulary coefficient. \\
If a value between $0.51-0.60$ is obtained through dividing the number of different words \\
used in the text by the total number of words the word repetitions in the text are \\
considered to be low, the richness of vocabulary is at a remarkable degree, and the text is \\
good in terms of vocabulary coefficient. \\
If a value between $0.31-0.50$ is obtained through dividing the number of different words \\
used in the text by the total number of words, the word repetitions in the text are \\
considered to be high and the text is considered medium in terms of the vocabulary \\
coefficient. \\
If a value between $0 .-0.3$ is obtained through dividing the number of different words \\
used in the text by the total number of words, the word repetitions in the text are \\
considered to be high, and the text is considered weak in terms of the vocabulary \\
coefficient.
\end{tabular}

Table 2. Vocabulary Coefficient Evaluation Scale (Bayburtlu, 2019)

\begin{tabular}{cc}
\hline Vocabulary coefficient & Value range \\
\hline Weak & $0-0.3$ \\
Intermediate & $0.31-0.50$ \\
Good & $0.51-0.60$ \\
Very good & $0.61-1$ \\
\hline
\end{tabular}

\section{Results}

The findings of the vocabulary coefficients of the texts in the Turkish textbooks examined were sorted and presented below

\subsection{Findings in the $5^{\text {th }}$ Grade Turkish textbooks by Antttepe Publishing}

The texts in the textbook were examined in themes, and the vocabulary coefficients were calculated. The findings are presented in table 3 .

Table 3. The vocabulary coefficients of 5th grade Anittepe Publishing Turkish textbook themes

\begin{tabular}{lll}
\hline Theme & Vocabulary Coefficient Value & Status of the theme \\
\hline 1.Individual and society & 0.29833333 & 1 (Weak) \\
\hline 2.National struggle and Ataturk & 0.28731241 & 1 (Weak) \\
\hline 3.Nature and the universe & 0.30287013 & 1 (Weak) \\
\hline 4.Our national culture & 0.34496310 & 2 (Intermediate) \\
\hline
\end{tabular}




\begin{tabular}{lll}
\hline 5.Citizenship & 0.34510374 & 2 (Intermediate) \\
\hline 6.Health and sports & 0.32301486 & 2 (Intermediate) \\
\hline 7.Virtues & 0.29803176 & 1 (Weak) \\
\hline 8.Science and technology & 0.49675024 & 2 (Intermediate) \\
\hline Total vocabulary coefficient & $\mathbf{0 . 3 3 7 0 4 7 5}$ & $\mathbf{2}$ (Intermediate) \\
\hline
\end{tabular}

When Table 3 is examined, it is seen that the vocabulary coefficient of the themes in Anittepe publishing 5th-grade Turkish textbook is 0.3370475 . The vocabulary coefficient of themes in the $5^{\text {th }}$ grade Turkish textbook corresponds to level 2 (intermediate). When the 5th-grade Turkish textbook is evaluated in terms of vocabulary coefficient, it is evaluated at the medium level as the Word repetitions in texts in themes are high.

When examining the values of the vocabulary coefficient of 8 themes in Table 3, it is seen that the lowest vocabulary coefficient is seen in the national struggle and Ataturk theme while the highest vocabulary coefficient is seen in the science and technology theme. The fact that none of the themes of the examined textbooks has a good or very good vocabulary coefficient is thought-provoking in terms of students' vocabulary development.

\subsection{Findings in the $6^{\text {th }}$ Grade Turkish textbook by MEB Publishing}

The texts in the textbook were examined in themes, and the vocabulary coefficients were calculated. The findings are presented in table 4.

Table 4. Vocabulary coefficients of texts in the 6th grade MEB Publishing Turkish textbook

\begin{tabular}{lll}
\hline Theme & VocabularyCoefficient Value & Status of the theme \\
\hline 1.Reading culture & 0.34154013 & 2 (Intermediate) \\
\hline 2.National struggle and Ataturk & 0.25175289 & 1 (Weak) \\
\hline 3.Science and technology & 0.30274031 & 1 (Weak) \\
\hline 4.Virtues & 0.32304370 & 2 (Intermediate) \\
\hline 5.Nature and the universe & 0.26401174 & 1 (Weak) \\
\hline 6.Our national culture & 0.29135703 & 1 (Weak) \\
\hline 7.Health and sports & 0.29825034 & 1 (Weak) \\
\hline 8.Individual and community & 0.34451030 & 2 (Intermediate) \\
\hline Total vocabulary coefficient & $\mathbf{0 . 3 0 2 1 5 0 8}$ & $\mathbf{1}$ (Weak) \\
\hline
\end{tabular}

Table 4 shows that the vocabulary value of the themes in the 6th grade Turkish textbook of MEB publications is 0.3021508 . This value is quite low in terms of the presence of vocabulary. The vocabulary of texts in the themes appears to be weak. The textbook's vocabulary coefficient of themes appears to have a general level of 1 (Weak) point. When the 6th-grade Turkish textbook is evaluated in terms of vocabulary coefficient, it is seen that the word repetitions in the texts in the themes are very high, and the texts are weak in terms of the vocabulary coefficient. According to Table 4 , it is understood that the theme with the lowest vocabulary coefficient is the National struggle and Atatürk, and the theme with the highest vocabulary coefficient value is the theme of the individual and society. None of the themes in the textbook has a good or very good vocabulary coefficient value. 


\subsection{Findings in the $6^{\text {th }}$ Grade Turkish textbook by Ekoyay Publishing}

The texts in the textbook were examined in themes and the vocabulary coefficients were calculated. The findings are presented in Table5.

Table5. Vocabulary coefficients of texts in the $6^{\text {th }}$ Grade Ekoyay Publishing Turkish textbook

\begin{tabular}{lll}
\hline Theme & VocabularyCoefficient Value & Status of the theme \\
\hline 1.Nature and universe & 0.33851203 & 2 (Intermediate) \\
\hline 2.National struggle and Ataturk & 0.24902791 & 1 (Weak) \\
\hline 3.Children's world & 0.34107430 & 2 (Intermediate) \\
\hline 4.Virtues & 0.34830149 & 2 (Intermediate) \\
\hline 5.Our national culture & 0.29574014 & 1 (Weak) \\
\hline 6. Science and technology & 0.42710418 & 2 (Intermediate) \\
\hline 7.Art & 0.39941031 & 2 (Intermediate) \\
\hline 8.Citizenship & 0.27610487 & 1 (Weak) \\
\hline Total vocabulary coefficient & $\mathbf{0 . 3 3 4 4 4 0 9 4}$ & $\mathbf{2}$ (Intermediate) \\
\hline
\end{tabular}

When Table 5 is examined, it is understood that the vocabulary coefficient of the themes in Ekoyay publishing 6th-grade Turkish textbook is 0.33444094 . It corresponds to level 2 (intermediate) in terms of the vocabulary coefficient value of the themes in the 6th-grade Turkish textbook. When the 6thgrade Turkish textbook is evaluated in terms of the vocabulary coefficient, it is understood that the text repetitions in the themes are high, and the texts are at the medium level in terms of the vocabulary coefficient. When the vocabulary coefficient values of the eight themes in Table 4 are examined, it is seen that the lowest vocabulary coefficient value belongs to the national struggle and Atatürk theme and the highest vocabulary coefficient value belongs to the Art theme. None of the textbook's themes has a good or very good vocabulary coefficient value indicates that the textbook is insufficient in terms of vocabulary acquisitions envisioned by the Turkish curriculum.

\subsection{Findings in the $7^{\text {th }}$ grade Turkish textbook by Özgün Publishing}

The texts in the textbook were examined in themes, and the vocabulary coefficients were calculated. The findings are presented in Table6.

Table 6. Vocabulary coefficients of reading texts in the 7th grade Özgün Publishing Turkish textbook

\begin{tabular}{lll}
\hline Theme & Vocabulary Coefficient Value & Status of the theme \\
\hline 1.Virtues & 0.386014231 & 2 (Intermediate) \\
\hline 2.National struggle and Ataturk & 0.234301453 & 1 (Weak) \\
\hline 3.Emotions & 0.289034737 & 1 (Weak) \\
\hline 4.Our national culture & 0.348014563 & 2 (Intermediate) \\
\hline 5.Nature and the Universe & 0.343501972 & 2 (Intermediate) \\
\hline 6.Art & 0.305014753 & 1 (Weak) \\
\hline 7.Personal development & 0.337301439 & 2 (Intermediate) \\
\hline 8.Science and technology & 0.376750341 & 2 (Medium) \\
\hline Total vocabulary coefficient & $\mathbf{0 . 3 2 7 4 9 1 6 2 5}$ & $\mathbf{2}$ (Medium) \\
\hline
\end{tabular}


When Table 6 is analyzed, the themes in the 7th grade Turkish textbook of Özgün publications are at the level of 2 (intermediate) with a vocabulary coefficient of 0.327491625 . This value shows that word repetitions are high in the texts in the themes and that the vocabulary of the text is not rich. The theme with the highest vocabulary coefficient is the virtues, while the theme with the lowest vocabulary coefficient is the National struggle and Ataturk. The theme with the highest value of the vocabulary coefficient after the theme of virtues is Science and Technology with 0.376750341 . The fact that the 7th-grade Turkish textbook has a medium-level vocabulary in terms of vocabulary coefficient value is a deficiency in terms of enriching students' vocabulary. None of the textbook's eight themes have been found to have a good or very good vocabulary coefficient value.

\subsection{Findings in the $7^{\text {th }}$ Grade Turkish textbook by MEB Publications}

The texts in the textbook were examined in themes, and the vocabulary coefficients were calculated. The findings are presented in table 7.

Table 7. Vocabulary coefficients of texts in the 7th grade Turkish Textbook by MEB Publications

\begin{tabular}{lll}
\hline Theme & VocabularyCoefficient Value & Status of the theme \\
\hline 1.Virtues & 0.33560147 & 2 (Intermediate) \\
\hline 2.National struggle and Ataturk & 0.32580374 & 2 (Intermediate) \\
\hline 3. Personal development & 0.35930504 & 2 (Intermediate) \\
\hline 4.Our national culture & 0.30174732 & 1 (Weak) \\
\hline 5. Science and technology & 0.38904683 & 2 (Intermediate) \\
\hline 6.Reading culture & 0.37149598 & 2 (Intermediate) \\
\hline 7.Nature and the universe & 0.39903647 & 2 (Intermediate) \\
\hline 8.Time and space & 0.30296581 & 1 (Weak) \\
\hline Total vocabulary coefficient & $\mathbf{0 . 3 4 8 1 2 5 3 7 5}$ & $\mathbf{2}$ (Intermediate) \\
\hline
\end{tabular}

Table 7 shows that the vocabulary coefficient value of the themes in the 7th grade Turkish textbook of MEB publications is 0.348125375 and corresponds to level 2 (Intermediate). The vocabulary coefficients of the texts are generally 2 (intermediate), which indicates that the word repetitions are high in the texts. According to the table, the theme with the highest vocabulary coefficient is the theme of Nature and the universe with 0.39903647 . The theme with the lowest vocabulary coefficient is the theme of National Culture with 0.30174732. As Turkish textbooks are the main materials of Turkish education, it is very important that they are rich in vocabulary. However, it is seen that the vocabulary of the Turkish textbook studied is not as rich as expected. This shows that textbooks, which are expected to enrich vocabulary, are weak in meeting the expectations.

\subsection{Findings in the $7^{\text {th }}$ Grade Turkish textbook by MEB Publications}

The texts in the textbook were examined in themes, and the vocabulary coefficients were calculated. The findings are presented in Table 8 . 
Table 8. Vocabulary Coefficients of Texts in the $7^{\text {th }}$ Grade Turkish Textbook by MEB Publications (Editor Emine KIRMAN)

\begin{tabular}{lll}
\hline Theme & Vocabulary Coefficient Value & Status of the theme \\
\hline 1. Emotions & 0.37457034 & 2 (Intermediate) \\
\hline 2.National struggle and Ataturk & 0.33684231 & 2 (Intermediate) \\
\hline 3.Reading culture & 0.30668303 & 1 (Weak) \\
\hline 4.Virtues & 0.38175047 & 2 (Intermediate) \\
\hline 5. Personal development & 0.31650473 & 2 (Intermediate) \\
\hline 6. Our national culture & 0.29153417 & 1 (Weak) \\
\hline 7.Health and sports & 0.25921049 & 1 (Weak) \\
\hline 8.Art & 0.30153758 & 1 (Weak) \\
\hline Total vocabulary coefficient & $\mathbf{0 . 3 2 1 0 7 9 1 2 5}$ & $\mathbf{2}$ (Intermediate) \\
\hline
\end{tabular}

AccordingtoTable8, the vocabulary value of the themes in the 7th grade Turkish textbook of MEB (Editor Emine KIRMAN) publications is 0.321079125 , which is low in terms of the vocabulary of themes. The vocabulary of texts in the themes is weak. The vocabulary coefficient of the themes in the textbook is generally at the level of 2 (Intermediate). When the 7th-grade Turkish textbook is evaluated in terms of the vocabulary coefficient, it is seen that the word repetitions in the texts in the themes are very high, and the texts are weak in terms of the vocabulary coefficient. According to Table 7, the theme with the lowest vocabulary coefficient of 0.225921049 is health and sports, and the theme with the highest vocabulary coefficient is virtues with 0.38175047 . It is seen that the themes in the 7th-grade Turkish textbook examined, as well as the themes of the other Turkish textbooks examined, do not have a good or very good vocabulary coefficient value. The fact that the texts in the themes belonging to the three different 7th-grade Turkish textbooks examined are not at the desired level in terms of providing vocabulary to students is worrying in terms of Turkish education.

\subsection{Findings in the $8^{\text {th }}$ Grade Turkish textbook by MEB Publications}

The texts in the textbook were examined in themes, and the vocabulary coefficients were calculated. The findings are presented in Table 9.

Table 9. Vocabulary coefficients of texts in the 8th grade MEB Publishing Turkish textbook

\begin{tabular}{lll}
\hline Theme & Vocabulary Coefficient Value & Status of the theme \\
\hline 1.Virtues & 0.34065348 & 2 (Intermediate) \\
\hline 2.National struggle and Ataturk & 0.33634037 & 2 (Intermediate) \\
\hline 3.Science and technology & 0.30859061 & 1 (Weak) \\
\hline 4.Individual and community & 0.37704734 & 2 (Intermediate) \\
\hline 5.Time and space & 0.34161072 & 2 (Intermediate) \\
\hline 6. Art as Our National Culture & 0.30637025 & 1 (Weak) \\
\hline 7. Nature and the Universe & 0.38227406 & 2 (Intermediate) \\
\hline 8.Citizenship & 0.39060718 & 2 (Intermediate) \\
\hline Total vocabulary coefficient & $\mathbf{0 . 3 4 7 9 3 6 7 5}$ & $\mathbf{2}$ (Intermediate) \\
\hline
\end{tabular}


When Table 9 is examined, the themes of the 8th-grade Turkish textbook are at the level of 2 (intermediate) with a vocabulary coefficient of 0.34793675 . In addition to teaching vocabulary to students, the 8th-grade Turkish course seeks to prepare students for entrance exams to high schools. In this exam, Turkish questions consist of highly rich texts in terms of vocabulary. 8th-grade Turkish textbook influences students' success in this exam. The fact that the Turkish textbook is insufficient in this respect poses a problem for the students. It is understood that the Word repetitions are high in the texts of the themes in the Turkish textbook examined. According to Table 8, the theme with the lowest vocabulary coefficient is National Culture with 0.30637025 , and the theme with the highest vocabulary coefficient is Citizenship with 0.39060718 . It was understood that the texts of the them of the Turkish textbook examined were not at the desired level in terms of providing students with vocabulary coefficients.

\section{Discussion}

In the study, 7 Turkish textbooks used in the 2019-2020 academic year were examined. The vocabulary coefficient of themes in the 5th-grade Turkish textbook by Anittepe Publishing was 0.3370475 . The vocabulary coefficient of themes in the 5th-grade Turkish textbook corresponds to level 2 (Medium). In similar studies, middle school Turkish textbooks were examined, and the results showed that the fun methods and techniques that will attract students and contribute to their vocabulary learning are not at the desired level (Karagöl\&Tarakc1,2019, p.167). It is very concerns for Turkish teaching that the vocabulary coefficients of themes are not at the desired level. The results in the vocabulary teaching are not at the desired level according to the results of this study and other similar studies. In the study, two 6th grade Turkish textbooks were examined. It was found that 2 textbooks by MEB publications and Ekoyay Publishing were not at the desired level in terms of vocabulary coefficients.

It was found that the vocabulary coefficient value of the texts of the themes in the 6th-grade Turkish textbook by MEB publications is 0.3021508, and it is at the level of 1 (Weak) point. The vocabulary coefficients of themes in the 6th-grade Turkish textbook by Ekoyay Publishing is 0.33444094 , which corresponds to level 2 (medium). Although the vocabulary coefficient of themes in the 6th-grade Turkish textbook by Ekoyay publishing is higher than the coefficient of themes in the 6th-grade Turkish textbook by MEB publications, both textbooks are not at the desired level in terms of vocabulary coefficient. According to the results of this study, both textbooks have high numbers of word repetitions, and their vocabulary is weak. The findings of this study are similar to the findings of Karadağ (2019). Karadağ (2019) found low levels of vocabulary coefficients in the 6th-grade Turkish textbooks. The fact that none of the themes in the two textbooks reviewed has a good or very good vocabulary coefficient value indicates that the textbook is insufficient in terms of the vocabulary learning outcomes as envisioned by the Turkish curriculum.

In the study, 37 th grade Turkish textbooks were examined that are: 7th grade Turkish textbook by ÖZGÜN publishing, 7th grade Turkish textbook by MEB publications, and 7th grade Turkish textbook by MEB Publications (Editor Emine Kirman). It was found that the themes in the 7th grade Turkish textbook of the Özgün publications were at the level of 2 (medium) with the vocabulary coefficient of 0.327491625 . The fact that the 7th-grade Turkish textbook has a moderate vocabulary in terms of the vocabulary coefficient stands out as a deficiency in enriching the vocabulary of students. It was found that the vocabulary coefficient of themes in the textbook of 7th grade Turkish textbook by MEB publications was 0.348125375 , which corresponds to level 2 (intermediate). Turkish textbooks are expected to be rich in vocabulary as they are the main teaching materials for Turkish education. 
However, the textbooks examined do not have a rich vocabulary as expected. This shows that the textbooks expected to enrich the vocabulary of students are weak in meeting the expectations. It was observed that the vocabulary coefficient of themes in the 7th grade Turkish textbook of the other MEB (Editor Emine KIRMAN) publications was 0.321079125. It is seen that the themes in the 7th-grade Turkish textbook examined, as well as the themes of the other Turkish textbooks examined, do not have a good or very good vocabulary coefficient value. The fact that the texts in the themes of the 3 different 7th-grade Turkish textbooks examined are not at the desired level in terms of vocabulary acquisition by students is concerning. A literature search showed that there are similar studies conducted on vocabulary in Turkish textbooks (Karagöl \& Tarakc1, 2019; Karadağ, 2019; Kurudayığlu \& Soysal, 2016; Baş \& Demirci, 2015; Sarıca, 2014; Yılmaz \& Doğan, 2014; Öz, 2012; Gül, 2009; Kurudayığlu \& Karadağ, 2006; Yıldırım, 2006; ArslanKutlu, 2006) with similar results obtained. In similar studies, it has been concluded that Turkish textbooks are weak in terms of vocabulary. There is no planning, activities, and practices in terms of providing vocabulary to students at the desired level.

It was found that the themes in the 8th-grade Turkish textbook examined in this study were at the level of 2 (intermediate) with a vocabulary coefficient of 0.34793675 . In addition to enriching students' vocabulary, the 8th-grade Turkish course seeks to prepare students for entrance exams to high schools as well. In this exam, Turkish lesson questions consist of rich texts in terms of vocabulary, and the 8th-grade Turkish textbooks are influential on students' success in this exam. The fact that the Turkish textbook is insufficient in this respect poses a problem for students. It is understood that the word repetitions are high in the texts of the themes in the Turkish textbook examined, and these texts were not at the desired level in terms of providing students with vocabulary. The fact that the vocabulary coefficient of the 8th-grade Turkish textbook's themes was low in the study is similar to the results in other studies in the literature (Kurudayığlu \& Karadağ 2006). The researchers examined 8th-grade Turkish textbooks in terms of vocabulary and determined that 8thgrade Turkish textbooks were weak in terms of vocabulary acquisition.

\section{Conclusion}

In this study, the reason why the vocabulary coefficients of the themes of the Turkish textbooks were examined was attributed to the subject-specific scopes and concept areas of the themes in the Turkish textbooks. The textbook authors select the texts of the themes according to these concept areas and subjects. Turkish curriculum obliged the authors of the textbook to include 8 themes. 5 of these themes are left to the preference of the authors. When 5 themes are prepared according to the author's personal preferences, vocabulary and the vocabulary coefficient of each theme show variances. Turkish textbooks are changed periodically. Also, Turkish textbooks used in Turkey in certain years are selected from books by different authors by region. Such practices cause difficulty in achieving a standard in the context of vocabulary acquisition in Turkish lessons. Considering that every Turkish textbook has a different vocabulary coefficient, it is possible that students don't have a standard vocabulary. A standard vocabulary coefficient value can be introduced in all grade-level textbooks or in themes as in this study in the Turkish curriculum. Textbook authors can also choose/write texts in the themes according to the average vocabulary coefficient value. While the texts placed in the themes are simplified, the textbook author can make the simplification process by taking into account the minimum vocabulary coefficient value that the theme should have. 


\section{Ethics Committee Approval}

The author(s) confirm(s) that the study does not need ethics committee approval according to the research integrity rules in their country (Date of Confirmation: December 11, 2020).

\section{References}

Akkül, A., Demirer, N., Gürcan, E., Karadaş, D.,Karahan, İ., \& Uysal, A. (2019). Ortaokul ve imam hatip ortaokulu Türkçe 7. Sınıf ders kitabı. Ankara: MEB Yayınları.

ArslanKutlu, H. (2006). MEB ilköğretim 6, 7. ve 8. Sinıf Türkçe ders kitaplarında yer alan metinlerin söz varlı̆̆ açısından değerlendirilmesi (Unpublished master's thesis). Marmara Üniversitesi Eğitim Bilimleri Enstitüsü, İstanbul.

Aru Akyüz, S., \& Ertem, S., İ. (2014). Türkçe ders kitaplarında kelime hazinesini geliştirmeye yönelik planlamanın incelenmesi. Turkish Studies-International Periodical for the Languages, Literature and History of Turkish or Turkic, 9(3), 675- 694.

Baş, B. (2011). Söz varlığı ile ilgili çalışmalarda kullanılacak ölçütler. Türklük Bilimi Araştırmaları, $29,27-61$.

Baş, B., \& Demirci, S. (2015). 2. Sınıf Türkçe ders kitabındaki metinlerle çalışma kitaplarındaki etkinliklerin söz varlığı açısından karşılaştırılması. Ana Dili Ĕgitimi Dergisi, 3(1),17-29.

Bayburtlu, Y. S. (2019). Ortaokul 6 ve 7. sınıf öğrencilerinin hazırlıksız konuşmalarında bağdaşıklık ve tutarlılı (Unpublished doctoral dissertation). Gazi Üniversitesi Eğitim Bilimleri Enstitüsü, Ankara.

Ceylan, S., Duru, K., Erkek, G., \& Pastutmaz, M. (2019). Ortaokul ve imam hatip ortaokulu Türkçe 6 ders kitabı. Ankara: MEB Yayınları.

Creswell, J. W. (2017). Eğitim araştırmaları:Nicel ve nitelar aş̧ırmanın planlanması yürütülmesi ve değerlendirilmesi.Ev. Kolektif. Ankara: Edam Eğitim Kitapları.

Çapraz Baran, Ş., \& Diren, E. (2019). Ortaokul ve imam hatip ortaokulu Türkçe 5 ders kitabı. Ankara: Anittepe Yayınları.

Demirel, T. (2019). Ortaokul ve imam hatip ortaokulu Türkçe 6. Sinıf ders kitabı. Ankara:Ekoyay Yayınları.

Erkal, H., \&Erkal, M. (2019). Ortaokul ve imam hatip ortaokulu Türkçe ders kitabı 7. sinıf. Ankara: Özgün Yayınc1lk.

Eselioğlu, H.,Set, S., \& Yücel, A. (2019). Ortaokul ve imam hatip ortaokulu Türkçe 8 ders kitabl. Ankara: MEB Yayınları.

Gül, D. (2009). İlköğretim 6. sinıf Türkçe ders kitaplarındaki kelime ögretiminde kullanılan etkinliklerin etkinliğine yönelik bir araştırma (Unpublished master's thesis), Sakarya Üniversitesi, Sakarya.

Karagöl, E., \& Tarakcı, R. (2019). Söz varlığı öğretimi açısından ortaokul Türkçe ders kitapları. Milli Ĕ̈itim Dergisi, 48(222), 149-171.

Karadağ, Ö., \& Kurudayığlu, M. (2010). 2005 Türkçe programına gore hazırlanmış ilköğretim birinci kademe Türkçe ders kitaplarının kelime hazinesi. Türklük Bilimi Araştırmaları, 27, 423-436. 
Karadă̆, Ö. (2018). Dil eğitimi araştırmaları için bir değişken önerisi: Kelime hazinesi katsayısı. Ana Dili Eğitimi Dergisi, 6(2),532-537.

Karadă̆, Ö. (2019). Aynı sınıf düzeyi için hazırlanan Türkçe ders kitaplarının ortak söz varlığı açısından karşılaştırılması. Ana Dili Eğitimi Dergisi, 7(4),1130-1140.

Kır, T., Kırman, E., \& Yağız, S. (2019). Ortaokul ve imam hatip ortaokulu Türkçe ders kitabı 7. Ankara: MEB Yayınları.

Kurudayığlu, M., \& Karadağ, Ö. (2006). Ortak kelime hazinesi kazandırmada ilköğretim sekizinci sınıf Türkçe ders kitaplarının durumu. Ahi Evran Üniversitesi Kırşehir Eğitim Fakültesi Dergisi, $7(2), 335-343$.

Kurudayığlu, M., \& Soysal, T. (2016). Cumhuriyet dönemi ortaokul Türkçe dersi öğretim programlarının söz varlığının geliştirilmesi açısından incelenmesi. Milli Eğitim Dergisi, $45(210), 115-140$.

MEB. (2019). İlköğretim Türkçe dersi öğretim programı (1-8. Sinıflar). Ankara: MEB.

Miles, M. B., \& Huberman, A. M. (1994). Qualitative data analysis: An expanded sourcebook (2nd ed.). USA: SAGE Publications.

Öz, G. (2012). İlköğretim sekizinci sınıf Türkçe ders kitaplarının söz varlığı bakımından incelenmesi (Unpublished master's thesis). İnönü Üniversitesi Eğitim Bilimleri Enstitüsü, Malatya.

Sarıca, A. (2014). İlköğretim II. Kademe Türkçe ders kitaplarındaki sözcük çalışmalarının yöntemteknik ve Türkçe ögretim programındaki kazanımlar açısından incelenmesi (Unpublished Master's thesis). Gazi Üniversitesi Eğitim Bilimleri Enstitüsü.

Türk Dil Kurumu. (2005). Türkçe Sözlük (10 $10^{\text {th }}$ ed.). Ankara: Türk Dil Kurumu Yayınları.

Yıldırım, A. F. (2006). Illköğretim ikinci sınıf Türkçe ders ve öğrenci çalışma kitaplarındaki kelime ögretim teknikleri üzerine bir inceleme (Unpublished master's thesis). Abant İzzet Baysal Üniversitesi Sosyal Bilimler Enstitüsü.

Yılmaz, T., \& Doğan, Y. (2014). 7. Sınıf öğrencilerinin anlamını bilmedikleri kelimeler ve Türkçe ders kitaplarında kelime çalışmaları bağlamında kelime öğretimi. Mustafa Kemal Üniversitesi Sosyal Bilimler Enstitüsü Dergisi, 11(25),279-295.

Yin, R. K. (2017). Durum çalışması araştırması uygulamaları. Ankara: Nobel Akademi. 


\section{Tematik kelime hazinesi katsayısı bakımından Türkçe ders kitapları}

\section{$\ddot{\mathbf{O} z}$}

Bu çalışma Türkçe ders kitaplarındaki temalara ait kelime hazinesi katsayılarını ortaya koymak amacıyla yapılan bir çalışmadır. Bu maksatla 20192020 eğitim öğretim yılında okutulan Türkçe ders kitapları incelenmiştir. Türkçe ders kitaplarının temalarına ait kelime hazinesi katsayıları çıkarılmıştır. Çalışmada 7 adet Türkçe ders kitabı temalar halinde kelime hazinesi katsayılarına göre incelenmiştir. Türkçe ders kitaplarına ait temaların kelime hazinesi katsayılarının incelenmiş olması araştırmanın iddiasına özgü bir yöntemdir. Türkçe ders kitaplarındaki temaların isimlerine özgü konu kapsamları ve kavram alanları vardır. Bu kavram konu kapsamları ve kavram alanlarına göre temalardaki metinler seçilmektedir. Seçilen metinlerin kelime hazinesi katsayıları da buna bağlı olarak değişmektedir. Bu sebepten ötürü Türkçe ders kitaplarının kelime hazinesi katsayıları tematik olarak hesaplanmıştır. Araştırmadan elde edilen bulgulara göre Türkçe ders kitaplarına ait temalarının kelime hazinesi katsayılarının düşük olduğu görülmüştür. İncelenen 7 adet ders kitabının temalarının hiçbirinde iyi ya da çok iyi düzeyde kelime hazinesi katsayısı değeri olmadığı görülmüştür. Türkçe ders kitaplarının öğrencilere kelime hazinesi kazandırma noktasında yeterli düzeyde olmadığı ve Türkçe dersi öğretim programının öngörülen kazanımlarını gerçekleştirme hususunda yetersiz olduğu anlaşılmıştır. Araştırmada Anıttepe yayıncılık 5. Sınıf Türkçe ders kitabında yer alan temaların kelime hazinesi katsayılarının değerinin 0,3370475 olduğu, MEB yayınlarına ait 6. sınıf Türkçe ders kitabının temalarına ait metinlerin kelime hazinesi katsayısı değerinin 0,3021508, Ekoyay yayıncılı̆ga ait 6. sınıf Türkçe ders kitabında yer alan temaların kelime hazinesi katsayılarının 0,33444094, Özgün yayınlarına ait 7. Sınıf Türkçe ders kitabında yer alan temaların 0,327491625, MEB yayınları 7. sınıf Türkçe ders kitabında yer alan temalara ait kelime hazinesi katsayısı değerinin 0,348125375 ve incelenen diğer ders kitabı olan MEB (Editör Emine KIRMAN) yayınları 7. sınıf Türkçe ders kitabındaki temalara ait kelime hazinesi değerinin 0,321079125olduğu görülmüştür. Araştırmada incelenen 8. Sınıf Türkçe ders kitabına ait temaların 0,34793675 kelime hazinesi katsayısı değeri olduğu sonucuna ulaşılmıştır.

Anahtar sözcükler: tematik kelime hazinesi, temaların kelime hazinesi katsayısı, kelime hazinesi katsayısı.

\section{AUTHOR BIODATA}

Yavuz Selim Bayburtlu is a Turkish language teacher who works in the Ministry of National Education in Kepez, Antalya. 